\title{
PEMBUATAN HAND SANITIZER BAGI UMKM DESA CICALENGKA KECAMATAN PAGEDANGAN KABUPATEN TANGERANG
}

\author{
Darmadi, N. Lilis Suryani, Ratna Sari, Rahmad Setiawan, Noto Susanto \\ Universitas Pamulang \\ Email: dosen02445@unpam.ac.id
}

\begin{abstract}
The purpose of this PKM activity is to provide training in making hand sanitizers to residents of Cicalengka Village, Pagedangan District, Tangerang Regency, Banten. The activity method used is to collaborate with residents of Ds.Cilengka Kec, Pagedangan.Kab, Tangerang -Banten by analyzing the problems in that place so that they can provide the right solution for residents of Ds.Cilengka Kec, Pagedangan.Kab, Tangerang Banten. After analyzing it, we provide training in the form of materials and practices with the aim that residents can make personal hand sanitizers.
\end{abstract}

\section{Keywords: PKM, Making Hand sanitizer}

\begin{abstract}
Abstrak
Tujuan dari kegiatan PKM ini adalah untuk memberikan pelatihan pembuatan hand sanitizer pada UMKM Desa Cicalengka Kecamatan Pagedangan Kabupaten Tangerang Banten. Metode kegiatan yang digunakan adalah bekerjasama dengan UMKM Ds.Cilengka Kec, Pagedangan Kab, Tangerang -Banten dengan memganalisis pemasalahan yang ada di tempat tersebut sehingga dapat memberikan solusi yang tepat bagi UMKM Ds. Cilengka Kec, Pagedangan Kab, Tangerang -Banten. Setelah di analisis maka kami memberikan pelatihan dalam bentuk materi dan praktek yang bertujuan UMKM bisa membuat hand sanitizer sendiri.
\end{abstract}

\section{Kata Kunci: PKM, Pembuatan Hand Sanitizer}

\section{A. PENDAHULUAN}

Kita semua tahu bahwa Negara Indonesia ini sedang tidak baik-baik saja. Pandemi Covid-19 sedang melanda di Negara tercinta kita. Presidn Joko Widodo mengabarkan teridentifikasinya dua UMKM Negara Indonesia terpapar virus Corona pada 2 Maret 2020. Setelah deklarasi tersebut, UMKM Indonesia berupaya bagaimana caranya agar virus Corona tidak menyebar. Dalam masa pandemi ini, menjaga kebersihan sangatlah diperlukan. Organisasi Kesehatan Dunia atau World Healt Organization (WHO) menjelaskan salah satu cara pencegahan penyebaran virus Corona adalah dengan membersihkan tangan secara teratur. Menurut penelitian, virus corona akan mati pada alkohol dengan kandungan $>60 \%$. Hand sanitizer rata-rata memiliki kandungan 90\% hingga 95\%, sehingga dinilai ampuh untuk membunuh virus corona yang sedang merebak dimanamana.

Bahan utama pembuatan hand sanitizer sendiri adalah isoropil alkohol dengan kandungan $>90 \%$ atau bisa diganti juga dengan menggunakan ethanol $96 \%$. Bahan lain dalam hand sanitizer yaitu gliserin yang berguna untuk mengentalkan larutan dan hidrogen peroksida sebagai bahan antiseptik ringan. Menurut Fatimah (2018) Hand sanitizer 
merupakan antiseptik untuk mencegah penumbuhan mikroorganisme dalam bentuk sediaan cairan yang penggunaannya tanpa menggunakan air.

Menurut Brealey, Myers dan Marcus, 2008. Hand sanitizer umumnya mengandung Ethyl Alkohol $62 \%$, pelembut, dan pelembab. Selain alkohol dan pelembut, hand sanitizer juga mengandung anti bakteri lain seperti tryclosan, gliserol, tannin, saponin dan agen antimikroba lainnya. Kandungan bahan aktif yang ada dalam hand sanitizer adalah alkohol yang memiliki efektivitas paling tinggi terhadap virus, bakteri, dan jamur juga tidak menimbulkan resistensi pada bakteri.

\section{B. METODE PELAKSANAAN KEGIATAN}

Metode kegiatan yang digunakan adalah bekerjasama dengan UKM Desa Cilengka. Metode kegiatan yang digunakan adalah bekerjasama dengan UMKM Desa Cilengka Kec, Pagedangan.Kab, Tangerang -Banten dengan memganalisis pemasalahan yang ada di tempat tersebut sehingga dapat memberikan solusi yang tepat dalam memberikan pelatihan membuat Hand sanitizer sendiri UMKM Desa Cilengka Kec, Pagedangan Kab,Tangerang -Banten. Setelah di analisis UMKM akan kami memberikan pelatihan dalam bentuk materi dan praktek yang bertujuan mengembangkan kemampuan untuk meningkatkan produktivtas bagi UMKM Desa Cilengka Kec, Pagedangan Kab, Tangerang -Banten yaitu pada tanggal 20-21 April 2021 sampai UMKM Desa Cilengka Kec, Pagedangan. Kab,Tangerang -Banten.

\section{HASIL DAN PEMBAHASAN}

Kegiatan pelaksanaan Pengandian Kepada Masayarakat adalah bekerjasama dengan UMKM Ds.Cilengka Kec, Pagedangan Kab, Tangerang -Banten dan mencari pemasalahan yang ada di tempat tersebut sehingga dapat memberikan solusi yang tepat dalam pentingnya kesehatan bagi UMKM Ds. Cilengka Kec, Pagedangan.Kab ,Tangerang -Banten. Setelah di analisis maka kami memberikan pelatihan dalam bentuk materi dan praktek dalam mengembangkan kemampuan pembuatan Hand sanitizer bagi UMKM Ds.Cilengka Kec, Pagedangan.Kab ,Tangerang -Banten.

Hasil dari pemberian materi pembuatan Hand sanitizer bagi UMKM Ds.Cilengka Kec, Pagedangan.Kab ,Tangerang -Banten. oleh dosen-dosen Fakultas Ekonomi Universitas Pamulang dan diskusi yang dilakukan saat kegiatan berlangsung dapat berguna bagi UMKM Desa Cicalengka Kecamatan Pagedangan Kabupaten Tangerang dalam meningkatkan keterampilan dan keilmuan mengenai pembuatan Hand sanitizer bagi UMKM Ds.Cilengka Kec, Pagedangan Kab,Tangerang -Banten. Dalam Meningkatkan Produktivitas Pada UMKM, sehingga dapat menjadikan UMKM Desa Cicalengka menjadi lebih produktif untuk dapat memajukan Usaha yang dirintis dengan baik. 

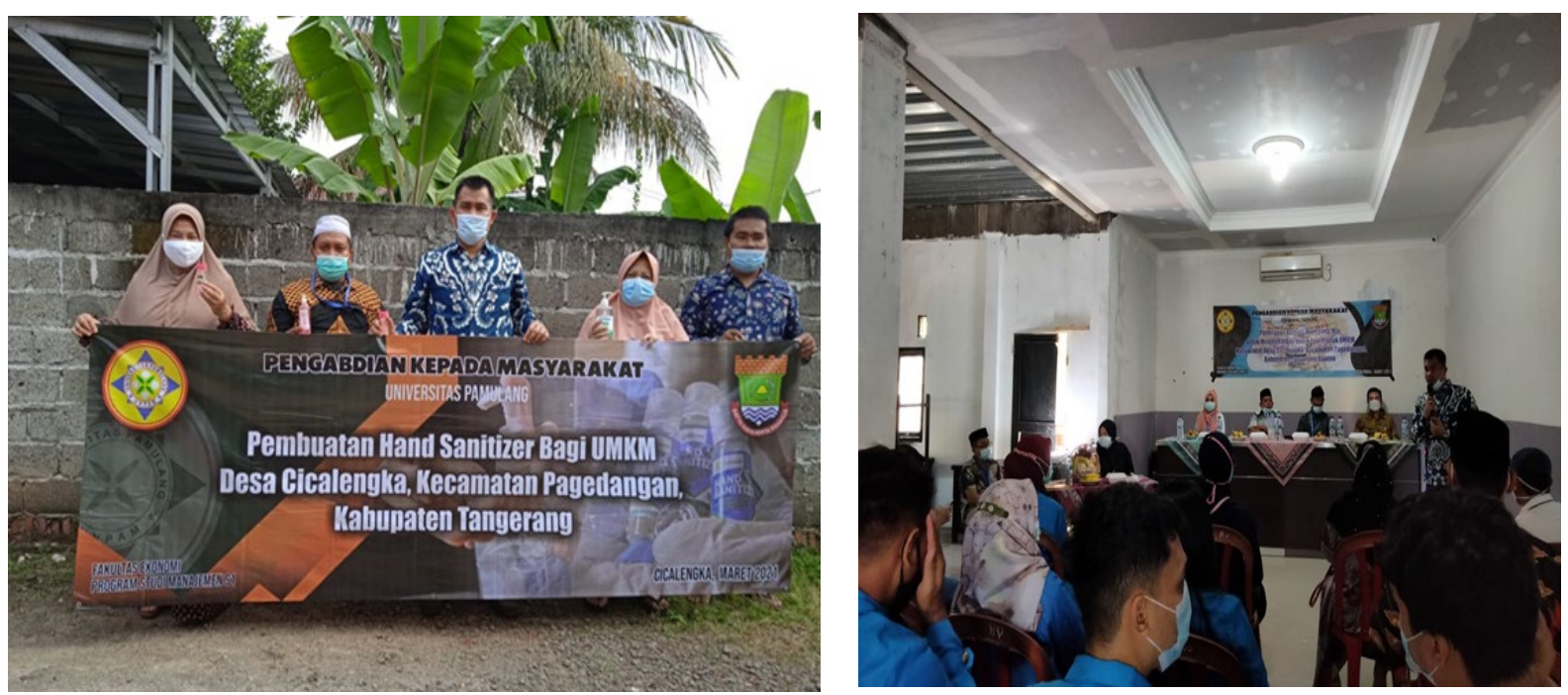

\section{Gambar 1. Photo Kegiatan PKM}

\section{KESIMPULAN}

Pelaksanaan kegiatan Pengabdian Kepada Masyarakat oleh Lembaga Penelitian dan Pengabdian Masyarakat (LPPM) Universitas Pamulang yang dilakukan oleh dosen-dosen program studi Manajemen telah berjalan dengan lancar dan mendapat sambutan hangat dari tempat pelaksanaan kegiatan ini yaitu kepala Desa Cilengka Kec, Pagedangan Kab, Tangerang. Harapan kami dengan pengabdian ini dapat menambah ilmu yang bermanfaat dalam pembuatan hand sanitizer pada UMKM Desa Cicalengka Kecamatan Pagedangan Kabupaten Tangerang Banten.

\section{DAFTAR PUSTAKA}

Darmadi. (2020), Pengaruh Lingkungan Kerja dan Disiplin Kerja Terhadap Kinerja Karyawan Pada Indomaret Cabang Kelapa Dua Gading Serpong Kabupaten Tangerang, JIMF (Jurnal Ilmiah Manajemen Forkamma), 3(3).

Darmadi., \& Setiawan, R. (2020), Analisis Implementasi Global Vision Melalui Straregi Pemasaran Perusahaan Roti Maulana Bakery Yang Berimplikasi Pada Daya Saing. Jurnal Ekonomi Efektif, 2(2).

Dewi, I. K., \& Solihin, D. (2020). Pengaruh Current Ratio Dan Net Profit Margin Terhadap Harga Saham Pada Perusahaan Makanan dan Minuman Yang Terdaftar Di Bursa Efek Indonesia (BEI) Periode 2015-2018. JURNAL ILMIAH FEASIBLE: Bisnis, Kewirausahaan \& Koperasi 2 (2), 183-191.

Dumilah, R., Sunarto, A., Solihin, D., \& Maulida, H. (2020). Pelatihan Pemanfaatan Media Sosial Untuk Promosi Usaha Atau Bisnis Bagi Siswa. DEDIKASI PKM, 1(1), 26-33.

Sari, R., Suryani, N. L., Setiawan, R., Susanto, N., \& Darmadi. (2020). Pengelolaan Sumber Daya Manusia Dalam Meningkatkan Produktivitas Pada Ukm Kelurahan Pagedangan Kabupaten Tanggerang-Banten. DEDIKASI PKM. 1(3), 93-97. 
Solihin, D., Susanto, N., Setiawan, R., Ahyani, \& Darmadi. (2020). Penerapan Strategi Pemasaran Sebagai Upaya Meningkatkan Usaha Kecil Dan Menengah Warga Di Kelurahan Paninggilan Utara Ciledug. ABDI LAKSANA, 1(3), 351-355.

Solihin, D., Prasetiyani, D., Sari, A. R., Sugiarti, E., \& Sunardi, D. (2020). Pemanfaatan Botol Bekas Sebagai Penyaring Air Bersih Sederhana Bagi Warga Desa Cicalengka Kecamatan Pagedangan Kabupaten Tangerang. DEDIKASI PKM, 1(3), 98-102.

Solihin, D. (2020), Faktor-Faktor Yang Mempengaruhi Kinerja Pemasaran Pada PT Prima Ufuk Semesta (Studi Empiris Pada Outlet Rekanan PT. Prima Ufuk Semesta di Wilayah JABODETABEK), Jurnal Semarak. 3(1).

Solihin, D. (2020), Pengaruh Kepercayaan Pelanggan Dan Promosi Terhadap Keputusan Pembelian Konsumen Pada Online Shop Mikaylaku Dengan Minat Beli Sebagai Variabel Intervening. Jurnal Mandiri: Ilmu Pengetahuan, Seni, dan Teknologi 4(1).

Solihin, D., dan Wibawanto, E. (2020). Pengaruh Kualitas Pelayanan, Harga, Dan Promosi Terhadap Keputusan Pelanggan Dalam Memilih Klub Basket Satria Indonesia Tangerang Selatan. Jurnal Pemasaran Kompetitif. 3(3).

Solihin, D. (2019), Pengaruh Current Ratio dan Debt To Equity Ratio Terhadap Return On Asset (ROA) Pada PT Kalbe Farma, Tbk. KREATIF: Jurnal Ilmiah Prodi Manajemen Universitas Pamulang. 7 (1), 115-122. 